\title{
Pengembangan Potensi Wisata Gastronomi Halal di Kabupaten Cianjur
}

\author{
Muhamad Syahpril Riano ${ }^{\text {, }}$ Caria Ningsih ${ }^{2}$, Hilman Taufiq Abdilah ${ }^{3}$ \\ 1,2,3Manajemen Industri Katering, Fakultas Ilmu Pendidikan Sosial, Universitas Pendidikan \\ Indonesia. Jl Dr. Setiabudhi No. 226, Kota Bandung, Indonesia \\ 15yahpril.16@Student.upi.edu, 22aria.ningsih@upi.edu, ${ }^{3}$ hilmantaufiq88@upi.edu
}

\begin{tabular}{l|l|l} 
Received: Month, Year & Accepted: Month, Year & Published: Month, Year
\end{tabular}

\begin{abstract}
Cianjur Regency is one of West Java's natural resource-rich districts. The purpose of this research is to inventory food and beverages, determine the attractiveness of halal gastronomic tourism in Cianjur Regency, and determine the extent of the Cianjur Regency government's development efforts. is demonstrating a halal gastronomic tour package. Qualitative and quantitative methods are used (mix method research). The data collection techniques used in this study were observation, questionnaires, and interviews. The results of this study were six food classifications, namely side dishes, sepinggan, snacks, souvenirs, chili sauce, and traditional drinks. Cianjur Regency had four major tourist attraction destinations. The government's efforts to develop gastronomic tourism have not been realized, as evidenced by the lack of a work program involving MUI. The Cianjur government is working to promote natural and historical tourism. The development of gastronomic tourism in Cianjur Regency is in Quadrant 1, and the strategy that must be used in this situation is to support an aggressive growth policy (Growth Oriented Strategy) and identify ten development strategies.
\end{abstract}

Keywords: halal tourism, gastronomic tourism, tour packages

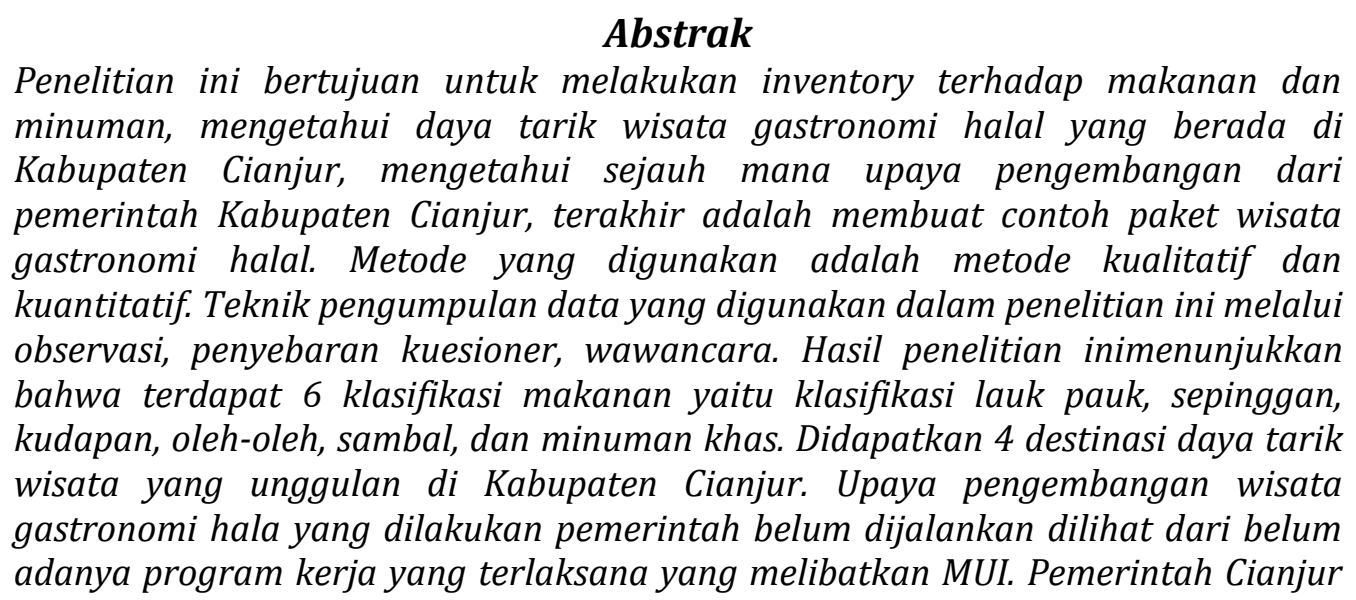


Muhamad Syahpril Riano, Caria Ningsih, Hilman Taufiq Abdilah

berfokus pada pengembangan wisata alam, sejarah. Pengembangan wisata gastronomi Kabupaten Cianjur berada pada Kuadran 1 dengan strategi yang harus diterapkan dalam kondisi ini adalah mendukung kebijakan pertumbuhan yang agresif (Growth Oriented Strategy) dan menemukan 10 strategi pengembangan.

Kata Kunci: wisata halal, wisata gastronomi, paket wisata

\section{PENDAHULUAN}

Pariwisata saat ini dijadikan suatu industri besar di berbagai negara termasuk Indonesia sebagai salah satu sebagai penghasil devisa negara dengan tujuan meningkatkan arus wisatawan yang masuk ke Indonesia, wisatawan mancanegara maupun wisatawan domestik, akan Pariwisata saat ini dijadikan suatu industri besar di berbagai negara termasuk Indonesia sebagai salah satu sebagai penghasil devisa negara dengan tujuan meningkatkan arus wisatawan yang masuk ke Indonesia, wisatawan mancanegara maupun wisatawan domestik, akan mendorong suatu aktivitas yang dapat menimbulkan dampak positif bagi suatu daerah/negara terutama dalam meningkatkan pertumbuhan suatu perekonomian negara, membuka peluang pekerjaan, mengurangi tingkat kemisikinan dan pengangguran.

Dalam perkembangan pasar internasioanl, perkembangan kunjungan pasar wisata muslim mengalami peningkatan yang tinggi dengan membaiknya keadaan negara-negara muslim di dunia. Perjalanan wisatawan Muslim Internasional semakin meningkat terutama yang berasal dari Timur Tengah kemenpar (dalam Republika, 2012). Kegiatan berbelanja wisatawan Muslim internasional mengalami peningkatan dari sebesar 126 Milyar Dollar pada tahun 2011 dan diprediksi akan meningkat sebesar 192 Milyar Dollar pada tahun 2020.

Indonesia sebagai negara yang mayoritas penduduknya muslim tersbesar didunia dengan populasi sebanyak 207 juta penduduk dan juga sebagai destinasi pariwasata di asia pasifik diharapkan bisa menjadi destinasi pariwisata syariah. Pada tanggal 17 November 2013, Presiden Susilo Bambang Yudhoyono mendeklarasikan Gerakan Ekonomi Syariah (GERS) yang diikuti oleh Program Pariwisata Syariah oleh Kementerian Pariwisata dan Ekonomi Kreatif. Pada tahun 2019 Indonesia menambah daftar penguatan pariwisata halal. Terdapat enam kabupaten/kota di Jawa Barat yang masuk dalam daftar wisata unggulan halal di Indonesia yaitu kota Tanjung Pinang, Pekanbaru, Bandung, Kabupaten Bandung Barat, Kabupaten Bandung, Kabupaten Cianjur.

Syarat utama dari destinasi yang menjadi tujuan wisata untuk segmen ini adalah makanan halal. Wisata halal bermakna industri yang di tujukan untuk wisata muslim dan pelayanannya merujuk pada aturan islam, artinya pemerintah akan melarang segala yang berhubungan dengan makanan yang haram maupun minuman yang haram dan memisahkan antara wanita dan pria yang non muhrim (Awalia, 2017).

Penelitian ini bertujuan untuk mengidentifikasi dan melakukan inventori terhadap makanan dan minuman halal khas Kabupaten Cianjur sebagai salah satu kota destinasi wisata halal di Indonesia. Selain itu, penelitian ini juga bertujuan untuk mengetahui daya tarik wisata gastronomi halal, upaya pengembangan wisata gastronomi halal dan paket wisata gastronomi halal di Kabupaten Cianjur.

\section{METODE PENELITIAN}

Metode dalam penelitian ini adalah mix methods, yaitu penggabungan antara metode penelitian kuantitatif dengan metode penelitan kualitatif. Metode tersebut mengumpulkan data dan menganalisis data kuantitatif dan kualitatif, penggunaan metode kuantitatif dengan teknik pengumpulan data berupa angket dan untuk metode kualitatif 
Muhamad Syahpril Riano, Caria Ningsih, Hilman Taufiq Abdilah

dengan teknik pengumpulan data berupa wawancara dengan narasumber dan observasi didukung dengan hasil dokumentasi dan di deskripsikan.

Penelitian ini menggunakan kuesioner untuk memeroleh informasi dari responden dan skala yang digunakan dalam kuesioner adalah skala Likert. Jumlah responden dalam penelitian ini adalah sebanyak 100 (seratus) orang yang mana responden tersebut dipilih dengan menggunakan teknik sampling incidental.

Penyebaran kuesioner dilakukan secara daring dengan menggunakan sarana Google Form kepada wisatawan domestik di Kabupaten Cianjur. Dalam pemilihan responden, peneliti menanyakan terlebih dahulu kepada calon responden, apakah calon responden memenuhi kriteria yang diajukan oleh peneliti atau tidak. Bila calon responden memenuhi kriteria yang diajukan oleh peneliti, maka calon responden berhak untuk mengisi kuesioner yang diberikan.

\section{HASIL DAN PEMBAHASAN}

\subsection{Validitas dan Reliabilitas}

Sebelum pegumpulan data dilakukan, pertanyaan di dalam kuesioner harus diuji terlebih dahulu untuk mengetahui validitas dan reliabilitasnya. Uji validitas dan realibitas dilakukan kepada 30 responden, sebagai syarat minimal untuk uji coba validitas dan realibitas. Cara pengukurannya adalah dengan menggunakan SPSS.

Untuk mengetahui apakah setiap butir pertanyaan valid atau tidak valid, harus memenuhi syarat-syarat berikut :

1) Jika rhitung $\geq$ rtabel, maka instrumen tersebut dinyatakan valid.

2) Jika rtabel $\geq$ rhitung, maka instrumen tersebut dinyatakan tidak valid.

Tabel 1 : Hasil Uji Validitas

[sumber: Data Diolah Penulis 2020]

\begin{tabular}{lllll}
\hline No & Variabel & Hitung & Tabel & Hasil Uji \\
\hline \multicolumn{5}{c}{ Faktor yang Memengaruhi Daya Tarik Wisata } \\
\hline 1 & X1 & 0,649 & 0,361 & VALID \\
2 & X1.2 & 0,694 & 0,361 & VALID \\
3 & X1.3 & 0,755 & 0,361 & VALID \\
4 & X1.4 & 0,736 & 0,361 & VALID \\
5 & X1.5 & 0,775 & 0,361 & VALID \\
6 & X1.6 & 0,671 & 0,361 & VALID \\
\hline \multicolumn{5}{c}{ Wisata Gastronomi Halal } \\
\hline 7 & X2 & 0,439 & 0,361 & VALID \\
8 & X2.2 & 0,650 & 0,361 & VALID \\
9 & X2.3 & 0,728 & 0,361 & VALID \\
10 & X2.4 & 0,644 & 0,361 & VALID \\
11 & X2.5 & 0,375 & 0,361 & VALID \\
12 & X2.6 & 0,804 & 0,361 & VALID \\
13 & X2.7 & 0,813 & 0,361 & VALID \\
14 & X2.8 & 0,778 & 0,361 & VALID \\
15 & X2.9 & 0,878 & 0,361 & VALID \\
16 & X2.10 & 0,823 & 0,361 & VALID \\
17 & X2.11 & 0,792 & 0,361 & VALID \\
18 & X2.12 & 0,763 & 0,361 & VALID \\
19 & X2.13 & 0,766 & 0,361 & VALID \\
20 & X2.14 & 0,771 & 0,361 & VALID \\
21 & X2.15 & 0,864 & 0,361 & VALID \\
22 & X2.16 & 0,813 & 0,361 & VALID \\
\hline \multicolumn{5}{c}{ Daya Tarik Wisatawan } \\
\hline 23 & Y1 & 0,630 & 0,361 & VALID
\end{tabular}


Muhamad Syahpril Riano, Caria Ningsih, Hilman Taufiq Abdilah

\begin{tabular}{lllll}
24 & Y2 & 0,722 & 0,361 & VALID \\
25 & Y3 & 0,718 & 0,361 & VALID \\
26 & Y4 & 0,739 & 0,361 & VALID \\
27 & Y5 & 0,599 & 0,361 & VALID \\
28 & Y6 & 0,723 & 0,361 & VALID \\
29 & Y7 & 0,752 & 0,361 & VALID \\
30 & Y8 & 0,626 & 0,361 & VALID \\
31 & Y9 & 0,607 & 0,361 & VALID \\
32 & Y10 & 0,782 & 0,361 & VALID \\
33 & Y11 & 0,713 & 0,361 & VALID \\
34 & Y12 & 0,740 & 0,361 & VALID \\
35 & Y13 & 0,682 & 0,361 & VALID \\
36 & Y14 & 0,477 & 0,361 & VALID \\
37 & Y15 & 0,516 & 0,361 & VALID \\
38 & Y16 & 0,531 & 0,361 & VALID \\
39 & Y17 & 0,555 & 0,361 & VALID \\
40 & Y18 & 0,443 & 0,361 & VALID \\
41 & Y19 & 0,632 & 0,361 & VALID \\
42 & Y20 & 0,715 & 0,361 & VALID \\
\hline
\end{tabular}

Nilai $r$ tabel untuk $n=30$ dan taraf kesalahan $(\alpha) 5 \%$ adalah sebesar 0,361 $(d b=n-2)$.

Berdasarkan hasil tabel di atas, dapat dilihat bahwa rata-rata nilai rhitung setiap variabel lebih besar dari nilai rtabel. Artinya, semua pernyataan yang terdapat di seluruh variabel penelitian adalah valid.

Uji reliabilitas dengan menggunakan SPSS yang akan dilakukan menggunakan Reliability Analysis Statistic dengan Cronbach Alpha ( $\alpha$ ). Jika nilai Cronbach Alpha $(\alpha)>$ 0.60 , maka dapat dikatakan variabel tersebut reliabel.

Tabel 2 : Hasil Uji Reabilitas

[sumber: Data Diolah Penulis 2020]

\begin{tabular}{c|c|c|c}
\hline $\begin{array}{c}\text { Cronbach } \\
\text { Alpha }\end{array}$ & $\begin{array}{c}\text { Nilai Minimal } \\
\text { Cronbach Alpha }\end{array}$ & $\begin{array}{c}\mathrm{N} \text { of } \\
\text { items }\end{array}$ & Hasil Uji \\
\hline 0,958 & 0,700 & 42 & Reliabel \\
\hline
\end{tabular}

Tabel di atas menunjukkan bahwa nilai Cronbach's Alpha untuk setiap variabel dalam penelitian ini lebih besar dari 0,60. Dengan demikian dapat ditarik simpulan bahwa seluruh pernyataan pada semua variabel penelitian adalah reliabel.

\subsection{Wisata Gastronomi Kabupaten Cianjur}

Melalui inventarisasi yang dilakukan terhadap makanan dan minuman yang terdapat di Kabupaten Cianjur dapat dikatagorikan kedalam lauk-pauk, makanan sepinggan, kudapan, oleh-oleh, sambal, dan minuman. Tabel 3 menunjukkan berbagai makanan dan minuman yang dapat dikatagorikan ke dalam kelompok tersebut.

Tabel 3 : Hasil Inventory Makanan dan Minuman [sumber: Data Diolah Penulis 2020]

\begin{tabular}{clr}
\hline No & Jenis Klasifikasi & Nama makanan \\
\hline 1 & Lauk pauk & Ikan bakar cianjur, pesmol kembung \\
2 & Makanan sepinggan & Geco, bubur ayam cianjur, laksa cianjur \\
3 & Kudapan & Manisan asinan,roti \\
4 & Oleh-oleh & Tauco, manisan, asinan, \\
5 & Sambal & Tauco,sambel hejo
\end{tabular}


Selain berbagai jenis makanan tersebut juga terdapat beberapa daya tarik wisata gastronomi halal di Kabupaten Cianjur, yaitu Taman Nasional Gunung Gede Pangrango, Kampung Wisata Pandan Wangi, Gunung Padang, dan Kampung Sarongge.

\subsection{Analisis Regresi Linear Berganda}

Analisis regresi linear berganda bertujuan untuk mengetahui arah hubungan antara variabel independen dan variabel dependen.

Tabel 4 : Hasil Analisis Regresi Linear Berganda [sumber: Data Diolah Penulis 2020]

\begin{tabular}{|c|c|c|c|c|c|c|}
\hline \multicolumn{7}{|c|}{ Coefficients $^{\mathbf{a}}$} \\
\hline \multirow{2}{*}{\multicolumn{2}{|c|}{ Model }} & \multicolumn{2}{|c|}{$\begin{array}{l}\text { Unstandardized } \\
\text { Coefficients }\end{array}$} & \multirow{2}{*}{$\begin{array}{c}\begin{array}{c}\text { Standardized } \\
\text { Coefficients }\end{array} \\
\text { Beta } \\
\end{array}$} & \multirow[t]{2}{*}{$\mathrm{t}$} & \multirow[t]{2}{*}{ Si g. } \\
\hline & & B & St d. Error & & & \\
\hline \multirow[t]{3}{*}{1} & (Constant) & 31,428 & 5,733 & & 5,482 & 000 \\
\hline & Daya tarik wisata & 1,162 & ,278 & ,384 & 4,181 & 000 \\
\hline & Gastronomi halal & ,314 &, 072 & ,402 & 4,379 &, 000 \\
\hline \multicolumn{7}{|c|}{ a. Dependent Variable: daya tarik wisata } \\
\hline
\end{tabular}

Berdasarkan hasil tabel, perumusan regresi dapat dirumuskan sebagai berikut : $\mathrm{Y}=31,428+1,162 \mathrm{X} 1+0,314 \mathrm{X} 2+\mathrm{e}$

Uji F dilakukan untuk mengetahui ada tidaknya pengaruh internet marketing dan electronic word of mouth terhadap motivasi berkunjung wisatawan secara simultan.

Tabel 5: Hasil Uji F

[sumber: Data Diolah Penulis 2020]

\begin{tabular}{|c|c|c|c|c|c|}
\hline \multicolumn{6}{|c|}{ Anova $^{2}$} \\
\hline Mo & & $\begin{array}{l}\text { Sum of } \\
\text { Squares }\end{array}$ & df & Mean Square $\quad F$ & Sig. \\
\hline \multirow[t]{3}{*}{1} & Regression & 5953.486 & 2 & $2976.743 \quad 36.765$ & .000 \\
\hline & Residual & 7853.674 & 97 & 80.966 & \\
\hline & Total & 13807.160 & 99 & & \\
\hline
\end{tabular}

a. Dependent Variable: MBW (Y)

b. Predictors: (Constant), EWOM (X2), IM (X1)

Berdasarkan tabel 4.4 dapat dilihat bahwa nilai sig $=0,000$ dengan nilai Fhitung sebesar 36,765 dan nilai Ftabel sebesar 3,94. Berdasarkan hasil perhitungan menunjukkan bahwa Fhitung $(36,765)>$ Ftabel $(3,94)$. Sehingga dapat disimpulkan bahwa internet marketing dan electronic word of mouth secara simultan memiliki pengaruh terhadap motivasi berkunjung wisatawan. Artinya, variabel internet marketing dan electronic word of mouth secara bersama-sama berpengaruh terhadap variabel motivasi berkunjung wisatawan.

Uji t dilakukan untuk melihat ada atau tidaknya pengaruh variabel bebas (Internet Marketing dan Electronic Word of Mouth) secara parsial terhadap variabel terikat (Motivasi Berkunjung Wisatawan). Hasil yang didapatkan adalah sebagai berikut: 
Tabel 6: Hasil Uji t

[sumber: Data Diolah Penulis 2020]

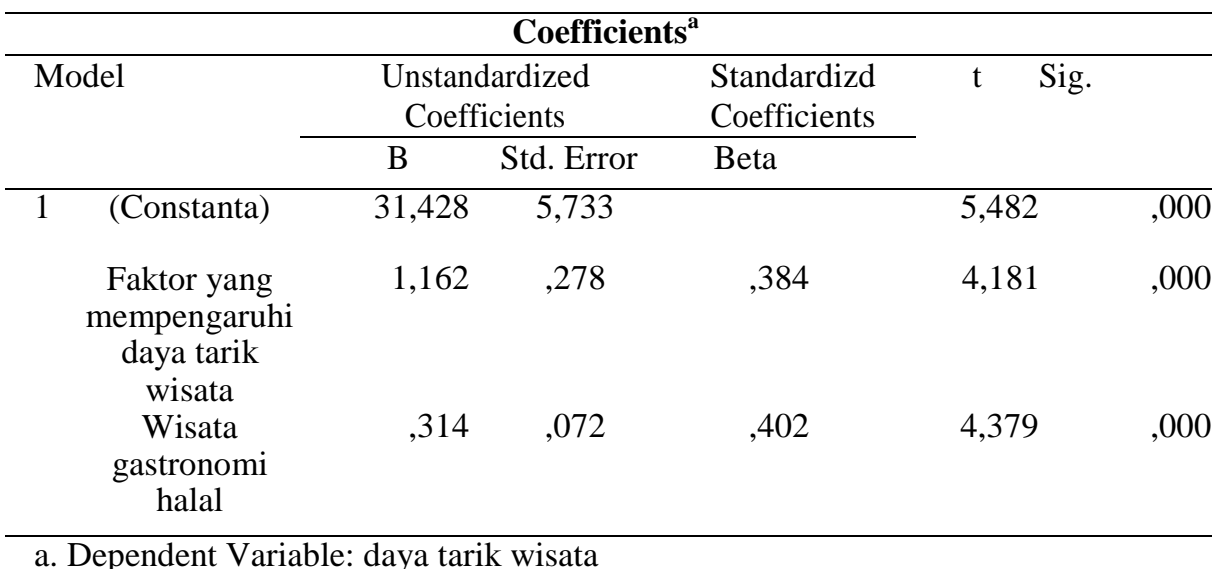

Berdasarkan tabel 6 diatas nilai signifikan variabel faktor yang mempengaruhi daya tarik wisata (X1) 0,000 < 0,05. Jadi dapat disimpulkan variabel (X1) faktor yang mempengaruhi daya tarik wisata berpengaruh secara positif dan signifikan terhadap daya tarik wisatawan. Berdasarkan tabel 6 diatas nilai signifikan variabel wisata gastronomi halal (X2) $0,000<0,05$. Jadi dapat disimpulkan variabel (X2) wisata gastronomi halal berpengaruh secara positif dan signifikan terhadap daya tarik wisatawan.

Koefisien determinasi digunakan untuk mengetahui seberapa besar variasi variabel dependen terhadap variabel independen. Nilai koefisien determinasi berkisar antara nol dan satu. Nilai yang mendekati satu berarti variabel independen (bebas) memberikan hampir semua informasi yang dibutuhkan untuk memprediksi variasi variabel dependen (terikat). Koefisien determinasinya (R square) sebesar 0,503 atau 50,3\%. Artinya pengaruh faktor yang mempengaruhi daya tarik wisata (X1) dan wisata gastronomi halal (X2) terhadap daya tarik wisatawan (Y) sebesar 50,3\% dan sisanya sebesar 49,7\% dipengaruhi faktor lain yang tidak diteliti oleh peneliti.

\subsection{Lingkungan Internal}

Menurut pekerja yang bekerja di perusahaan itu biasanya diadakan pelatihan. Dalam proses pengolahan pekerja memiliki tugasnya masing- masing, jadi dalam kualitas ini pekerja memiliki kemampuan masing-masing dibidangnya dan semua bidang. Dan perusahaan ini juga menekankan pada para pekerja untuk saling bantu.

Pekerja yang dibutuhkan dalam proses pembuatan adonan di perusahaan ini ada 10 orang masing-masing memiliki tugas berbeda-beda ada yang mengerjakan adonan roti, yang bakar roti dalam oven, cetak roti jadi semua pekerja tidak ada yang diam semua bekerja sampai waktu istirahat.

Target pasar nya adalah semua kalangan yang tinggal didaerah cianjur maupun dari luar cianjur yang berwisata, karena produk olahan nya murah-murah harganya. Perusahaan ini menggunakan metode pemasaran dari dulu hingga sekarang dengan cara bekerja sama dengan masyarakat sekitar pabrik untuk bantu jual, dan dijual menggunakan gerobak dorong maupun diam ditempat di trotoar dekat pabrik di jalan cokroaminoto.

Sumber modal perusahaan ini adalah dari keluarga, lalu dibantu dengan keringanan suplier yang memberikan kredit bahan- bahan dengan memberi waktu untuk membayarnya. Cara mengelola keuangannya tidak didapatkan jawabannya. 
Bahan bakunya selalu ada karena ada suplier yang mengirim bahan-bahan dan supliernya berada di cianjur, tidak sama seperti dahulu kala bahan bakunya harus impor dari luar negeri.

1) Proses Produksi

Tidak ada teknik khusus yang digunakan dalam pengolahan adonan roti pada perusahaan tang ken $\mathrm{cu}$, sama hal nya pembuatan adonan roti yang banyak yaitu dengan mesin agar memudahkan dan mengefisienkan waktu, uniknya mesin yang digunakan adalah warisan dari pertama perusahaan buka dan oven nya juga masih sama sejak buka perusahaan hingga sekarang bedannya pada bahan bakarnya.

2) Hasil Produksi

Hasil produksi nya sendiri di jual di toko sendiri dan di jajakan dengan gerobak keliling sekitaran tempat pengolahannya.

3) Kualitas dan kuantitas produk

Proses produksi tidak memakai bahan pengawet, jadi terjamin keamanannya, namun produk tidak bertahan lama maksimal 3 hari. Produk dijajakan dalam keadaan fresh from oven dalam jumlah yang banyak, sehingga waktu terbaik untuk membeli produk ini adalah saat pagi hari.

\subsection{Lingkungan Eksternal}

Analisis lingkungan mikro berdasarkan penyebaran kuesioner kepada wisatawan yang sudah berkunjung ke Kabupaten Cianjur. Kuesioner yang peneliti susun disebar ke wisatawan melalui media sosial yang dimiliki oleh peneliti sebanyak 100 responden. Tujuannya adalah untuk mengetahui tanggapan wisatawan mengenai potensi wisata gastronomi di Kabupaten Indramayu dapat dilihat dari tanggapan responden tentang variabel daya tarik wisata dengan empat aspek, yaitu attractions/atraksi, amenities/fasilitas,accesibilities/aksesibilitasdan ancillary service/ pelayanan tambahan. Variabel wisata gastronomi dengan 8 komponen, yaitu masak- memasak/kuliner, filosofi, sejarah, tradisi, dan sosial, bahan baku, mencicipi, menghidangkan, mempelajari, meneliti, dan menulis makanan, mencari pengalaman makan yang unik, dan pengetahuan gizi. Serta variabel persepsi wisatawan dengan tiga aspek yaitu aspek kognitif, aspek afektif dan aspek konatif.

Analisis Faktor Eksternal lingkungan makro berdasarkan pedoman wawancara dengan Majelis Ulama Indonesia dan Perhimpunan Hotel dan Restoran Indonesia. Tujuan dari pedoman wawancara yang telah disusun oleh peniliti adalah untuk mengetahui tanggapan dan pandangan mengenai analisis potensi pengembangan wisata gastronomi di Kabupaten Cianjur.

Adapun factor-faktor yang menjadi kekuatan

1) Terdapat wisata alam dan wisata sejarah, terdapat wisata alam seperti curug, taman nasional gunung gede pangrango, pantai di pesisir selatan dan terdapat wisata sejarah seperti gunung padang.

2) Terdapat makanan dan kuliner khas yang halal dikabupaten cianjur, seperti tauco, roti tang ken $\mathrm{cu}$, manisan, pesmol cianjur, bubur ayam cianjur dan Bajigur.

3) Harga jual makanan khas cianjur terbilang murah selain murah juga banyak.

4) Kemudahan akses jaringan internet dan mudah menjangkau jaringan nya.

5) Mendapatkan pengalaman unik saat berkunjung ke cianjur.

6) Kedua perusahaan yang diwawancarai produknya tidak mengg unakan bahan pengawet.

7) Kedua perusahaan yang diwawancarai produknya tidak menggunakan bahan pengawet.

8) Membantu perekonomian masyarakat sekitar daerah pengolahan, dengan cara membantu menjualkan produk dan bagi hasil.

Faktor-faktor yang menjadi kelemahan adalah: 
Muhamad Syahpril Riano, Caria Ningsih, Hilman Taufiq Abdilah

1) Tidak ada paket wisata khusus gastronomi halal

2) Bahan baku pada perusahaan tauco sebagian besar masih import dari amerika.

3) Produk roti tidak tahan lama

4) Filosofi dan sejarah makanan mulai memudar

5) Belum adanya kajian tentang wisata gastronomi halal di kabupaten Cianjur menurut MUI

6) MUI sudah lama mengajukan kepada pemerintah untuk membantu UMKM dalam pembiayaan sertifikasi, dan pemerintah sudah mau mengabulkan. Tapi sejauh ini belum ada realisasi. Bagaimana bentuk bantuannya, juga belum ada kejelasan.

Faktor-faktor yang menjadi peluang adalah:

1) Wisatawan sangat mendukung pemerintah kabupaten Cianjur Mengembangkan Wisata Gastronomi Halal di Kabupaten Cianjur, selain itu potensi yang dimiliki Kabupaten Cianjur banyak, terutama pada Kuliner dan Wisata alamnya.

2) Cianjur menjadi salah satu tempat terdekat dari ibu kota jakarta, jadi memiliki peluang wisatawan banyak berkunjung.

3) Cianjur menjadi salah satu kabupaten yang di tunjuk pemerintah untuk dikembangkan wisata halalnya.

Faktor yang menjadi ancaman

1) Wisatawan memilih menggunakan pribadi dibanding menggunakan kendaraan umum yang memiliki tour guide.

2) Banyaknya pesaing makanan yang menjual makanan modern.

3) Semakin maraknya pelabelan tanpa pendaftaran dan audit dari MUI, membuat konsumen ragu untuk membeli.

\subsection{Strategi Pengembangan}

Berdasarkan hasil dari matriks IFE dan EFE di atas, langkah selanjutnya adalah menentukan titik sumbu $X$ yaitu matrik IFE $(1,97$ total kekuatan - 0,84 total kelemahan)= 1,13 maka posisi sumbu $\mathrm{X}$ adalah pada titik 1,13. Sedangkan sumbu Y yaitu matriks EFE $(1,29$ total peluang $-0,91$ total ancaman $)=0,38$, maka posisi sumbu $Y$ adalah pada titik 0,38. Dibawah gambar yang menunjukkan positioning Kabupaten Cianjur memiliki potensi wisata gastronomi Halal :

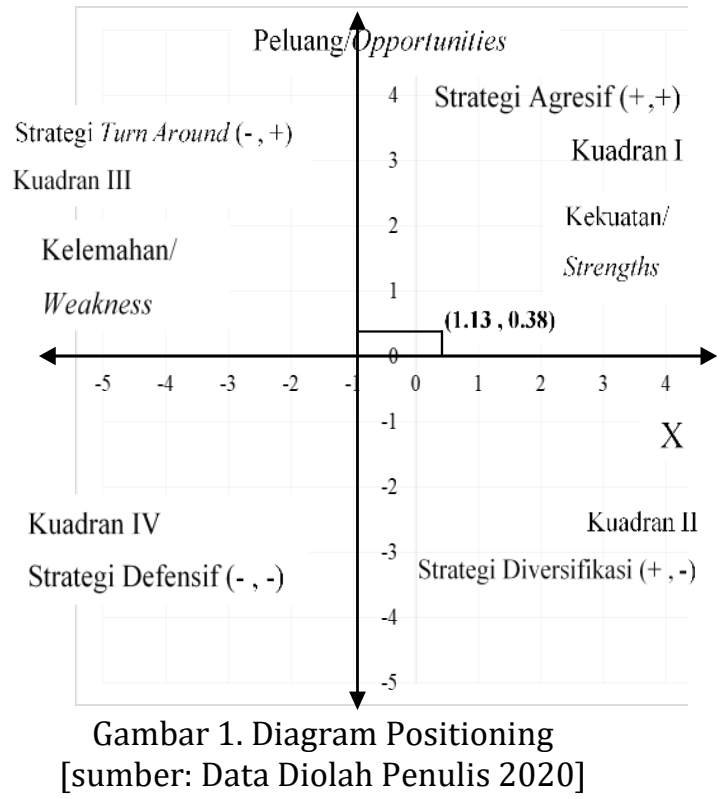


Berdasarkan gambar 4. Menunjungak bahwa potensi wisata gastronomi halal di Kabupaten Cianjur berada di posisi kuadran I dengan strategi yang harus diterapkan dalam kondisi ini adalah mendukung kebijakan pertumbuhan yang agresif (Growth Oriented Strategy). Pengembangan potensi wisata gastronomi halal di Kabupaten Cianjur memiliki kekuatan sehingga dapat memanfaatkan peluang yang ada, serta dapat menanggulangi kelemahan dan ancaman.

\subsection{Analisis Matrik SWOT}

Analisis Matriks SWOT merupakan langkah untuk menentukan strategi potensi berdasarkan Matriks IFE dan Matriks EFE, yaitu dengan strategi SO (strenght Opportunities), ST (Strenght Threats), WO (Weakness Opportunities) dan WT (Weakness Threats). Lebih lengkapnya sebagai berikut :

\begin{tabular}{|c|c|c|}
\hline \multirow[t]{2}{*}{ Internal/Eksternal } & Kekuatan (Strenght) & Kelemahan (Weakness) \\
\hline & $\begin{array}{l}\text { 1) Terdapat wisata alam dan } \\
\text { wisata sejarah, terdapat wisata } \\
\text { alam seperti curug, taman } \\
\text { nasional gunung gede } \\
\text { pangrango, pantai di pesisir } \\
\text { selatan dan terdaapat wisata } \\
\text { sejarah seperti gunung padang. } \\
\text { 2) Terdapat makanan dan kuliner } \\
\text { khas yang halal dikabupaten } \\
\text { cianjur, seperti tauco, roti tang } \\
\text { ken cu, manisan, pesmol } \\
\text { cianjur, bubur ayam cianjurdan } \\
\text { Bajigur. } \\
\text { 3) Harga jual makanan khas } \\
\text { cianjur terbilang murah selain } \\
\text { murah jugabanyak. } \\
\text { 4) Kemudahan akses jaringan } \\
\text { internet dan mu mudah } \\
\text { menjangkau jaringan nya } \\
\text { 5) Mendapatkan pengalaman unik } \\
\text { saat berkunjung ke cianjur } \\
\text { 6) Tempat wisata aksesnya baik } \\
\text { 7) Kedua perusahaan yang } \\
\text { diwawancarai } \\
\text { menggunakan bahan pengawet } \\
\text { pada produknya. } \\
\text { 8) Membantu perekonomian } \\
\text { masyarakat sekitar daerah } \\
\text { pengolahan dengan cara } \\
\text { membantu menjualkan produk } \\
\text { dan bagi hasil. }\end{array}$ & $\begin{array}{l}\text { 1) Tidak ada paket wisata } \\
\text { khusus gastronomi halal } \\
\text { 2) Bahan baku pada } \\
\text { perusahaan tauco } \\
\text { sebagian besar masih } \\
\text { import dari amerika. } \\
\text { 3) Produk roti tidak tahan } \\
\text { lama } \\
\text { 4) Filosofi dan sejarah } \\
\text { makanan mulai memudar. } \\
\text { 5) Belum adanya kajian } \\
\text { tentang wisata gastronomi } \\
\text { halal di kabupaten } \\
\text { Cianjur menurut MUI. } \\
\text { 6) MuI sudah lama } \\
\text { mengajukan kepada } \\
\text { pemerintah untuk } \\
\text { membantu uMKM dalam } \\
\text { pembiayaan sertifikasi, } \\
\text { dan pemerintah sudah } \\
\text { mau man membantu } \\
\text { menjualkan produk dan } \\
\text { bagi hasil. }\end{array}$ \\
\hline Peluang (Opportunities) & $\begin{array}{l}\text { Strategi So (Strenght } \\
\text { Opportunities) }\end{array}$ & $\begin{array}{l}\text { Strategi Wo(Weakness } \\
\text { Opportunities) }\end{array}$ \\
\hline $\begin{array}{l}\text { 1) Wisatawan sangat } \\
\text { mendukungpemerintah } \\
\text { kabupaten Cianjur } \\
\text { Mengembang ban } \\
\text { Wisata Gastronomi } \\
\text { Halal di Kabupaten } \\
\text { Cianjur, selain itu } \\
\text { potensi yang dimiliki } \\
\text { Kabupaten Cianjur } \\
\text { banyak, terutama pada } \\
\text { Kuliner dan Wisata } \\
\text { alamnya. } \\
\text { 2) Cianiur menjadi salah } \\
\text { satu tempat terdekat } \\
\text { dari ibu kota iakarta. } \\
\text { iadi memiliki peluang } \\
\text { wisatawan banyak } \\
\text { berkunjung. } \\
\text { 3) Cianjur menjadi salah } \\
\text { satu kabupaten yang di } \\
\text { tunjuk pemerintah } \\
\text { untuk dikembangkan } \\
\text { wisata halalnya }\end{array}$ & $\begin{array}{l}\text { Mengaptimal ban semua } \\
\text { potensi yang ada di Kabupaten } \\
\text { Cianjur mulai dari Wisata alam, } \\
\text { Makanan halal, wisata } \\
\text { gastronomi halalnya serta dapat } \\
\text { membantu perekonomian } \\
\text { masyarakat, (S1, S2, S3,S5, S7, } \\
\text { S8, 01). } \\
\text { 2) Dapat menarik wisatawan } \\
\text { yang berkuniung secara tidak } \\
\text { langsung wisatawan yang } \\
\text { berkunjung dapat } \\
\text { memperkenal kan pariwisata } \\
\text { halal di Kabupaten Cianjur. (S4, } \\
\text { o2). } \\
\text { 3) Pemerintah } \\
\text { mengembangkan wisata } \\
\text { gastronomi halal di kabupaten } \\
\text { Cianjur. barus bekeria sama } \\
\text { dengan stakeholder maupun } \\
\text { pengusaha yang ada (S6,03). }\end{array}$ & $\begin{array}{l}\text { 1) Pemerintah bersama } \\
\text { agen-agen travel dan } \\
\text { pengusaha harus bisa } \\
\text { memanfaatkan peluang } \\
\text { bahwa kabupaten cianjur } \\
\text { merupakan salah satu } \\
\text { daerah yang akan } \\
\text { dikembangkan wisatanya } \\
\text { oleh pemerintah. } \\
\text { (W1,W4,W5, W6,01,03) } \\
\text { 2) Perusahaan harus bisa } \\
\text { memanfaatkan potensi } \\
\text { Wisatawan terdekat untuk } \\
\text { membeli bahan } \\
\text { makanannya yang tidak } \\
\text { tahan lama, dan juga } \\
\text { memanfaatkan bahan } \\
\text { baku campuran local dan } \\
\text { import agar harga tidak } \\
\text { mahal. (W2, w3, 02) }\end{array}$ \\
\hline
\end{tabular}




\begin{tabular}{|c|c|c|}
\hline Ancaman (Thread) & StrategiST (Strenght Threats) & $\begin{array}{l}\text { Strategi WT (Weakness } \\
\text { Threats) }\end{array}$ \\
\hline $\begin{array}{l}\text { 1) Wisatawan memilih } \\
\text { menggunakan kendaraan } \\
\text { pribadi dibanding } \\
\text { menggunakan kendaraan } \\
\text { umum yang memiliki } \\
\text { tourguide, dapat dilibatdari } \\
\text { hasil kuesioner yang di isi } \\
\text { oleb responden. } \\
\text { 2) Banyaknya pesaing } \\
\text { makanan yang meniual } \\
\text { makanan modern. } \\
\text { 3) Semakin maxaknya } \\
\text { pelabelan tan tanpa } \\
\text { pendaftaran dan audit dari } \\
\text { MUI, membuat kousumen } \\
\text { ragu untukmembeli. }\end{array}$ & 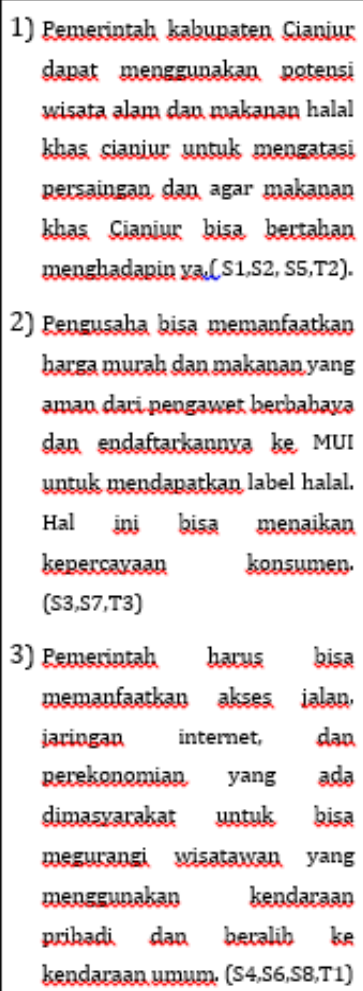 & 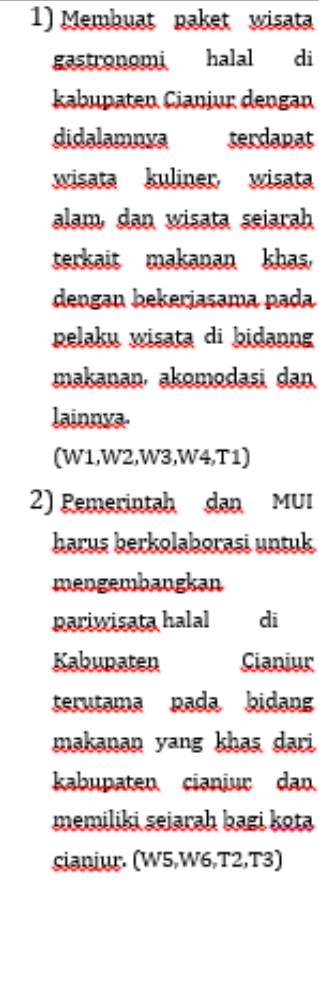 \\
\hline
\end{tabular}

Gambar 2: Hasil Analisis Matrik SWOT

[sumber: Data diolah Penulis, 2020]

\subsection{Paket Wisata Gastronomi Halal}

Paket wisata ini menawarkan wisata yang berkaitan dengan makanan halal khas Kabupaten Cianjur. Selain itu wisatawan juga bisa melihat proses pembuatan dan membeli produk setelah melihat pengolahannya. Disamping itu, terdapat wisata alam dan kuliner yang bisa dinikmati oleh wiastawan.

Tabel 7 : Wisata Gastronomi Halal Kabupaten Cianjur [sumber: Data diolah Penulis, 2020]

\begin{tabular}{ll}
\hline Nama Paket Wisata & Wisata Gastronomi Halal \\
Highlight & Belajar dan makan halal \\
Harga & Rp550.000 \\
Minimum pax & 4 \\
Transportasi & Mobil \\
Durasi & 1 hari \\
Kontak & \\
\hline
\end{tabular}


Pengembangan Potensi Wisata Gastronomi Halal di Kabupaten Cianjur

Muhamad Syahpril Riano, Caria Ningsih, Hilman Taufiq Abdilah

\begin{tabular}{|c|c|c|c|c|}
\hline \multicolumn{5}{|c|}{ Rencana Perjalanan } \\
\hline Waktu & Kegiatan & Deskripsi Kegiatan & Lokasi & Harga \\
\hline $\begin{array}{l}07.00- \\
07.30\end{array}$ & Meeting point & - & $\begin{array}{l}\text { Hotel } \\
\text { BYDIEL }\end{array}$ & Rp400.000/malam \\
\hline $\begin{array}{l}08.00- \\
09.00\end{array}$ & $\begin{array}{l}\text { Berkunjung ke } \\
\text { pengolahan } \\
\text { roti tangkeng } \\
\text { cun untuk } \\
\text { breakfast }\end{array}$ & $\begin{array}{l}\text { Melihat kegiatan } \\
\text { pembuatan roti sebelum } \\
\text { breakfast }\end{array}$ & $\begin{array}{l}\text { Jl. HOS } \\
\text { Cokro Aminoto } \\
\text { No.95, Muka, Kec. } \\
\text { Cianjur, Kabupat en } \\
\text { Cianjur, Jawa Barat } \\
43215\end{array}$ & $\begin{array}{l}\text { Harga roti mulai } \\
\text { dari Rp3.000- } \\
\text { Rp5.000/bungkus }\end{array}$ \\
\hline $\begin{array}{l}09.00- \\
10.00\end{array}$ & $\begin{array}{l}\text { Berkunjung ke } \\
\text { kampung } \\
\text { wisata beras } \\
\text { pandan wangi }\end{array}$ & $\begin{array}{l}\text { Menikmati } \\
\text { pemandangan, melihat } \\
\text { proses pengolahan beras } \\
\text { dan meggunjungoi } \\
\text { museum tani }\end{array}$ & $\begin{array}{lr}\text { Desa } & \text { Mekarwangi } \\
\text { kec. } & \text { Warung } \\
\text { Kondang } & \end{array}$ & Gratis \\
\hline $\begin{array}{l}11.00- \\
12.00\end{array}$ & Makan siang & $\begin{array}{l}\text { Istirahat dan makan di } \\
\text { rumah makan khas } \\
\text { sunda yaitu Alam Sunda } \\
\text { yang terkenal dengan } \\
\text { kelezatan sambalnya }\end{array}$ & $\begin{array}{l}\text { Solokpandan, Jl. HOS } \\
\text { Cokroaminoto } \\
\text { No.11, Muka, Kec. } \\
\text { Cianjur, Kabupaten } \\
\text { Cianju, Jawa } \\
\text { Barat,43215 }\end{array}$ & Rp2.000-Rp40.000 \\
\hline $\begin{array}{l}12.00- \\
12.30\end{array}$ & Istirahat & $\begin{array}{l}\text { Kegiatan lain wisatawan } \\
\text { dan beribadah }\end{array}$ & $\begin{array}{lr}\text { Alun-alun } & \text { dan } \\
\text { masjid } & \text { agung } \\
\text { Cianjur } & \end{array}$ & \\
\hline $\begin{array}{l}12.30- \\
14.00\end{array}$ & $\begin{array}{l}\text { Wisata } \\
\text { kampung } \\
\text { sarongge }\end{array}$ & $\begin{array}{l}\text { Melihat proses } \\
\text { pembuatan the sereh } \\
\text { dengan bahan segar dari } \\
\text { kebun warga, menikmati } \\
\text { hamparan perkebunan } \\
\text { teh }\end{array}$ & $\begin{array}{l}\text { Jl. Pasir Sarongge } \\
\text { Desa Ciputri, Kec. } \\
\text { Pacet, Kabupaten } \\
\text { Cianjur, Jawa Barat, } \\
43253\end{array}$ & Rp90.000 \\
\hline $\begin{array}{l}14.30- \\
15.30\end{array}$ & $\begin{array}{l}\text { Wisata } \\
\text { Cibodas }\end{array}$ & $\begin{array}{l}\text { Jalan-jalan di taman dan } \\
\text { membeli oleh-oleh }\end{array}$ & $\begin{array}{lr}\text { Taman } & \text { Nasional } \\
\text { Gunung } & \text { Gede } \\
\text { Pangrango } & \end{array}$ & $\begin{array}{l}\text { Rp32.000 tiket } \\
\text { masuk dan parkir } \\
\text { mobil }\end{array}$ \\
\hline $\begin{array}{l}16.00- \\
17.00\end{array}$ & $\begin{array}{l}\text { Berkunjung ke } \\
\text { pengolahan } \\
\text { tauco cap } \\
\text { meong }\end{array}$ & $\begin{array}{l}\text { Melihat proses } \\
\text { pengolahan dan belaja } \\
\text { rsejarah tauco, membeli } \\
\text { tauco }\end{array}$ & $\begin{array}{l}\text { Jl. HOS } \\
\text { Cokroaminoto, } \\
\text { solokpandan, kec. } \\
\text { Cianjur, Kab. Cianjur, } \\
\text { Jawa Barat,43214 }\end{array}$ & $\begin{array}{ll}\text { Mulai } & \text { dari } \\
\text { Rp.15.000 } & \end{array}$ \\
\hline $\begin{array}{l}17.30- \\
1830\end{array}$ & $\begin{array}{l}\text { Kembali ke } \\
\text { hotel }\end{array}$ & istirahat & BYDIEL & \\
\hline $\begin{array}{l}19.00- \\
20.00\end{array}$ & Belanja & $\begin{array}{l}\text { Mendatangi pusat } \\
\text { perbelanjaan oleh- } \\
\text { oleh(manisan,mochi,asin } \\
\text { an dan lain-lain) }\end{array}$ & $\begin{array}{l}\text { Sekitar jalan } \\
\text { Cokroaminoto }\end{array}$ & \\
\hline
\end{tabular}

Selesai Perjalanan

Paket termasuk enterance fee, penginapan, parking fee, pemandu wisata, makan berat $2 \mathrm{x}$, kudapan $2 \mathrm{x}$, welcome drink, souvenir

\section{KESIMPULAN}

Berikut adalah kesimpulan yang didapatkan berdasarkan hasil penelitian dan pengujian :

1) Indentifikasi makanan halal pada 10 makanan khas Kabupaten Cianjur menggunakan 9 komponen gastronomi dengan menggunakan studi literatur dan wawancara. Diambil contoh dilakukan pada dua perusahaan pengolahan roti tan keng cu dan tauco cap 
meong khas Cianjur ini memiliki sertifikasi halal. Dilihat dari pengolahannya, bahan, kebersihan tempat dan alat bahwa makanan tersebut halal. Setiap makanan memiliki filosofi nya masing-masing, makna yang terkandung dalam nama itu adalah gambaran dari pengaruh budaya maupun sejarah pada sebelum berdirinya, dari 10 makanan itu klasifikasikan sebagai lauk-pauk ikan bakar cianjur, pesmol cianjur, selanjut nya klasifikasi makanan sepinggan (terdapat karbohidrat, protein dan vitamin dalam 1 piring), Geco, bubur ayam cianjur, laksa cianjur. Kudapan, roti dan asinan/manisan. Oleh-oleh, tauco, manisan, asinan, sambalnya ada sambal hejo dan tauco minumannya ada bandrek cap 2 pigeon.

2) Kabupaten Cianjur memiliki daya tari wisata, dari wisata alam, wisata sejarah, wisata edukasi, wisata alam terdapat Taman Nasional Gunung Gede Pangrango terdapat curug, taman bermain, taman bunga untuk edukasi, selain itu juga tempat konservasi flora dan fauna yang sudah terancam punah.

3) Pengembangan potensi wisata gastronomi halal di kabupaten cianjur terdapat pada kuadran 1 dengan strategi yang harus diterapkan dalam kondisi ini adalah mendukung kebijakan pertumbuhan yang agresif (growth oriented strategy), dari hasil analisis didapatkan 10 alternatif strategi yang dapat digunakan untuk pengembangan wisata gastronomi halal di kabupaten Cianjur. Dari strategi pengembangan untuk kabupaten cianjur bisa mengoptimalkan potensi wisata nya mulai dari wisata alam, gastronomi halalnya untuk membantu perekonomian. Selain itu harus adanya koordinasi stakeholder terkait agar sejalan.

4) Hasil akhir penelitian ini adalah peneliti membuat paket wisata gastronomi halal, guna mengkoordinir wisata gastronomi halal di Kabupaten Cianjur. Paket wisata ini memiliki beberapa kegiatan dan kunjungan ke tempat wisata, paket wisata ini bertujuan untuk meberikan panduan pada wisatawan yang berkunjung ke Kabupaten Cianjur. Paket wisata juga dapat membantu pemerintah mengkaji dan membuat kebijakan kepariwisataan di Kabupaten Cianjur.

\section{DAFTAR PUSTAKA}

Adisasmito, W. (2008). Analisis Kebijakan Nasional MUI dan BPOM dalam Labeling Obat dan Makanan. Universitas Stuttgart.

Awalia, H. (2017). Komodifikasi Pariwisata Halal NTB dalam Promosi Destinasi Wisata Islami di Indonesia. Jurnal Studi Komunikasi (Indonesian Journal of Communications Studies), 1(1),19-30. https://doi.org/10.25139/jsk.v1i1.64

Budiaji, W. (2013). Skala Pengukuran dan Jumlah Respon Skala Likert (The Measurement Scale and The Number of Responses in Likert Scale). Ilmu Pertanian Dan Perikanan, 2(2), 127-133.

David, M. E., David, F. R., \& David, F. R. (2009). The Quantitative Strategy Planning (QSPM) applied to a retail computer store. 53(9), 1689-1699. https://doi.org/10.1017/CB097811074 15324.004

Djafkar, M. (2016). membangun wacana integrasi perundangan nasional dengan syariah.

Faraudis, Z., Andiani, N. D., Rahmawati, P. I. (2019). Bingkai Halal dan Non Halal : Studi Kasus Penerapan Halal Food di Restoran Spice Beach Club Bali. 2(2), 1-9.

Guzel, B., \& Apaydin, M. (2017). Gastronomy Tourism: Motivations and Destinations. Global Issues and Tends in Tourism, (January), 394-404.

Hidayat, A. S., \& Siradj, M. (2015). Sertifikasi Halal dan Sertifikasi Non Halal pada Produk Pangan Industri. AHKAM: Jurnal Ilmu Syariah, 15(2), 199-210. https://doi.org/10.15408/ajis.v15i2.2864.

Imelda, J. (2015) Laporan Dialog Gastronomi Nasional.

Ismayati. (2010). Pengantar Pariwisata. Jakarta: Grasindo. 
Majelis Ulama Indonesia. (2019). Majelis Ulama Indonesia - MUI.OR.ID. 8917(51), 2020. Retrieved from https://mui.or.id/Badan Pusat Statistik. (2016). Kota dan Kabupaten Jawa Barat Dalam Angka 2016. Jawa Barat: Badan Pusat Statistika Jawa Barat.

Maryani. (2013). Objek Dan Daya Tarik Wisata.

Meyers, K. (2009). Panduan Dasar Pelaksanaan Ekowisata.

Syifaun, N. (2003). Pengertian Perencanaan. http://rumohkuta.blogspot.com/ 2013/02/Pengertian-perancangan.html diakses pada 20 Deseber 2019

Ningsih, C. (2016). Sinergitas Industri Kreatif Berbasis Pariwisata Dengan Strategi Pembangunan Industri Nasional Menuju Globalisasi. Sinergitas Industri Kreatif Berbasis Pariwisata Dengan Strategi Pembangunan Industri Nasional Menuju Globalisasi, 11(1), 59-64. https://doi.org/10.17509/jurel.v11i1.29 03

Rifa'i, M. N. (2018). Promosi Makanan Halal di Kota Taipei, Taiwan. FALAH: Jurnal Ekonomi Syariah, 3(1), 111. https://doi.org/10.22219/jes.v3i1.6515

Sugiyono. (2017). Metode Penelitian Bisnis. (Edisi Ke-3; S. Y. Suryandari, Ed.). Bandung

Paulista, U. E., Em, P. D. E. P., \& Biológicas, C. (2014). ASEAN Tourism Crisis Comm Manual.

Pressman, R. (2012). Rekayasa Perangkat Lunak. Yogyakarta : Andi.

Semiawan, C. R. (2010). Metode Penelitian Kualitatif. Jakarta: Grasindo.

Soekadijo, R, G. (2000). Anatomi Pariwisata Memahami Pariwisata sebagai systrmic linkage. Jakarta: PT.Gramedia Pustaka Utama.

Turgarini, D. (2018). Gastronomi Sunda Sebagai Daya Tarik Wisata Kota Bandung. Universitas Gadjah Mada, Yogyakarta.

Undang-Undang Republik Indonesia Nomor 10 tahun 2009 Kepariwisataan.

Utama, I. G. B., \& M, N. M. E. (2012). Metodologi Penelitian Pariwisata dan Perhotelan. Yogyakarta: CV Andi. 